\title{
THE VERTICAL DISTRIBUTION OF THE ALLUVIAL CHEMO-FACIES OF BOUMERZOUG WADI, CONSTANTINE, NORTHEASTERN ALGERIA: PALEOENVEROMENTAL SIGNIFICANCE AND CLIMATE EVOLUTION
}

\author{
Noureddine RABAHI * \\ Faculty of Exact Sciences, Sciences of Nature and Life, University LarbiTebessi, Route de Constantine, 12002, \\ Tebessa, Algeria; Water Resources, Mobilization and Management Laboratory (LMGRE) University of Batna-2-, Algeria, \\ e-mail: n.rabahi@univ-batna2.dz
}

\section{Foued DJAIZ}

Water Resources, Mobilization and Management Laboratory (LMGRE) University of Batna -2-, Algeria, e-mail: djaizfou@yahoo.fr

\section{Nabil DEFAFLIA}

Faculty of Exact Sciences, Sciences of Nature and Life, University Larbi Tebessi, Route de Constantine, 12002, Tebessa, Algeria, e-mail: defaflianabil@yahoo.fr

\section{Enrico GUASTALDI}

GeoExplorer Impresa Sociale S.r.1., Via E. Vezzosi, 15 - 52100 Arezzo, Italy

CGT Center for GeoTechnologies, University of Siena, Via Vetri Vecchi, 34 - 52027 San Giovanni Valdarno, Italy e-mail: guastaldi@geoexplorersrl.it

\author{
Abdelouahab AMROUNE \\ Faculty of Sciences, Department of Agronomic Sciences, University of M'Sila,BP: 166, M'Sila 28000, Algeria, \\ e-mail: amroune.abdelouahab@gmail.com
}

Citation: Rabahi, N, Djaiz, F., Defaflia, N., Guastaldi, E., Amroune, A. (2021). The Vertical Distribution of the Alluvial Chemo-Facies of Boumerzoug Wadi, Constantine, Northeastern Algeria: Paleoenveromental Significance and Climate Evolution. Analele Universităţii din Oradea, Seria Geografie, 31(1), 68-79. https://doi.org/10.30892/auog.311108-865

\begin{abstract}
The authorities of Constantine city have been working on the redevelopment and calibration of the Rhumel and Boumerzoug wadis since 2015. The latter calebrage works caused great damage to the banks, thus affecting the Quaternary geological formations in place (alluvial terraces, flood plains). A multidisciplinary research project based on a geomorphological and sedimentological approach was quickly set up to create a scientific data base before their total destruction and loss of physical traces all along the wadis. The present study focuses on the sedimentological and geochemical analysis of the alluvial deposits of Boumerzoug wadi in order to describe the sediments, to reconstitute their nature, and to interpret both the climatic evolution and the paleo-environments of the region. Sedimentological and geochemical results confirm the succession of deposition cycles linked to progressive climate change.
\end{abstract}

Key words: Algeria, Boumerzoug wadi, alluvial deposits, geochemical facies, climate change 
$* \quad * \quad * \quad * \quad * \quad *$

\section{INTRODUCTION}

Alluvial deposits present an important archive of environmental changes through hydroclimatic cycles (Salvia-Castellvi et al., 2002). These sediments can record changes in paleowater flow, which is an approximation of precipitation rates and climate (Salvia-Castellvi et al., 2002). Almost all the studies aimed at reconstructing the Quaternary paleoclimates in the Maghreb from geological formations were based on morphological, sedimentological and/or pedological analyses (Wengler et al., 1992). Constantine region is situated between latitude $36^{\circ} 23^{\prime}$ and longitude $7^{\circ} 35^{\prime}$ in the middle of the Eastern Algeria, $245 \mathrm{~km}$ far from the Algerian-Tunisian borders, Constantine considered the third largest city in Algeria.

The main wadis of the Constantine basin are part of a geographical context that clearly presents contrasting aspects from upstream to downstream: the flat and bare reliefs and rather loose river system of the high plains are followed by the low Tellian Atlas hills and deep valleys, which are extending to the north by mountainous massifs affected by a high drainage density (Keddari et al., 2019; Mébarki, 1984). This work is essentially based on a two-steps method, careful field observations, and granulometric and geochemical analysis of sediments in laboratory. The aim of this approach is to describe the sediments, identify their geochemistry and reconstitute the nature of the alluvium linked essentially to the Boumerzoug wadi's activity, also providing important information on the climate and its evolution. Then, the main objective of this work is to clarify the importance of the contribution of river deposition studies in highlighting hydrodynamic variations during sedimentation and their climatic significance.

\section{STUDY AREA}

The studied outcropping sections of Boumerzoug wadi (figure 1) are located in the central part of the high Constantinian plains, a well-individualized mountainous ensemble that presents a fragmented morphology with vast plains covered by Plio-Quaternary deposits (Rabahi, 2008).

Boumerzoug wadi, a tributary of Rhumel wadi, located south of Constantine, drains a watershed of $1,868 \mathrm{~km}^{2}$, appearing in a collapse basin shape, dominated by isolated and abrupt horst reliefs. The $50 \mathrm{~km}$ long Boumerzoug wadi receives several tributaries on its path, the most important of which is the Hamimime wadi (Bourenane and Bouhadad, 2021; figure 1). Morphologically, these sections are located in the eastern plains of the Tellian Atlas, whose altitude varies between 500 and $800 \mathrm{~m}$ asl and it is characterized by a contrasting relief flanked by deep gorges, plateaus and hills (figure 2c; Rabahi, 2008).

Downstream from Boumerzoug wadi, the valley is cut into a raised calcareous relief, forming gorges more than $150 \mathrm{~m}$ high.

The highest slopes (over 30\%) are mainly distributed close to the watercourses of which they form the banks. The lowest slopes (0 to 10\%) represent a significant proportion of the morphology of the region (figure $2 \mathrm{~d}$ ). They essentially correspond to the alluvial terraces of the Boumerzoug wadi and its tributaries.

The downstream course of Boumerzoug wadi is characterized by the development of meanders just at the entrance to Constantine town. The widening of the valley, where the terraces and the major riverbed take a large extension, makes the sprawl of the flood in the alluvial plain more spectacular (Bougdal, 2007; figure 3). The developed meanders reveal an escarpment on the concave bank, which takes the form of a long, steep slope of several dozen of meters.

The lobe of the convex bank is highly developed and reveals different beds whose limits are materialized by the presence of slopes of the metric order (figure $2 b$ ).

From a hydrographic and climatic point of view, the plains are dotted with numerous wadis (figure 1, figure 2e), the majority of which converges towards the Rhumel wadi, the most important hydrographic element of the Constantine region. 
The Rhumel wadi crosses the high plains of Constantine region following a NE-SW orientation until its confluence with the Boumerzoug wadi, then it flows through the gorges across the Rock of Constantine, NW-SE oriented (Rabahi, 2008; Farah, 1991). Two main climates types prevail in the Constantine region (Côte, 1974). The northwestern region is characterized by a subhumid climate with mild winters, dry and hot summers, while the southwestern one shows a semi-arid climate with cold winters and dry, hot summers (Côte, 1974). The combination of precipitation and temperatures helps to define bioclimatic domains. The climate of the study area is of the semi-arid type $(300-350<\mathrm{P}<550-600 \mathrm{~mm})$. Is characterized by alternating dry seasons (June to September) and wet seasons (October to April), with a heat of $25-45^{\circ} \mathrm{C}$ in summer and a cold of $0-12{ }^{\circ} \mathrm{C}$ in winter (Mébarki, 1984).

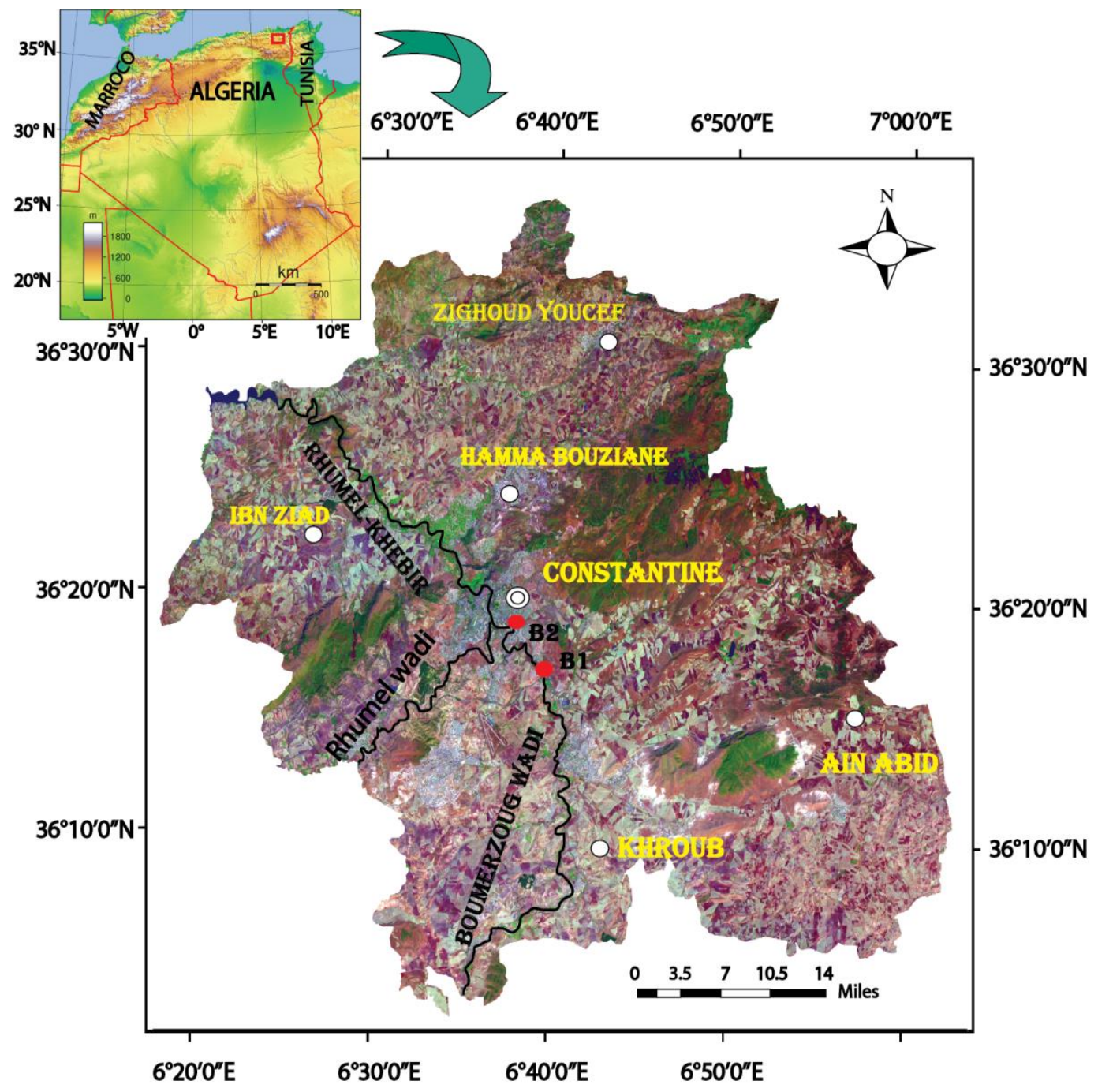

Figure 1. Photo map of the study area location (B1; section 1, B2 section 2) (Source: Landsat Image) 

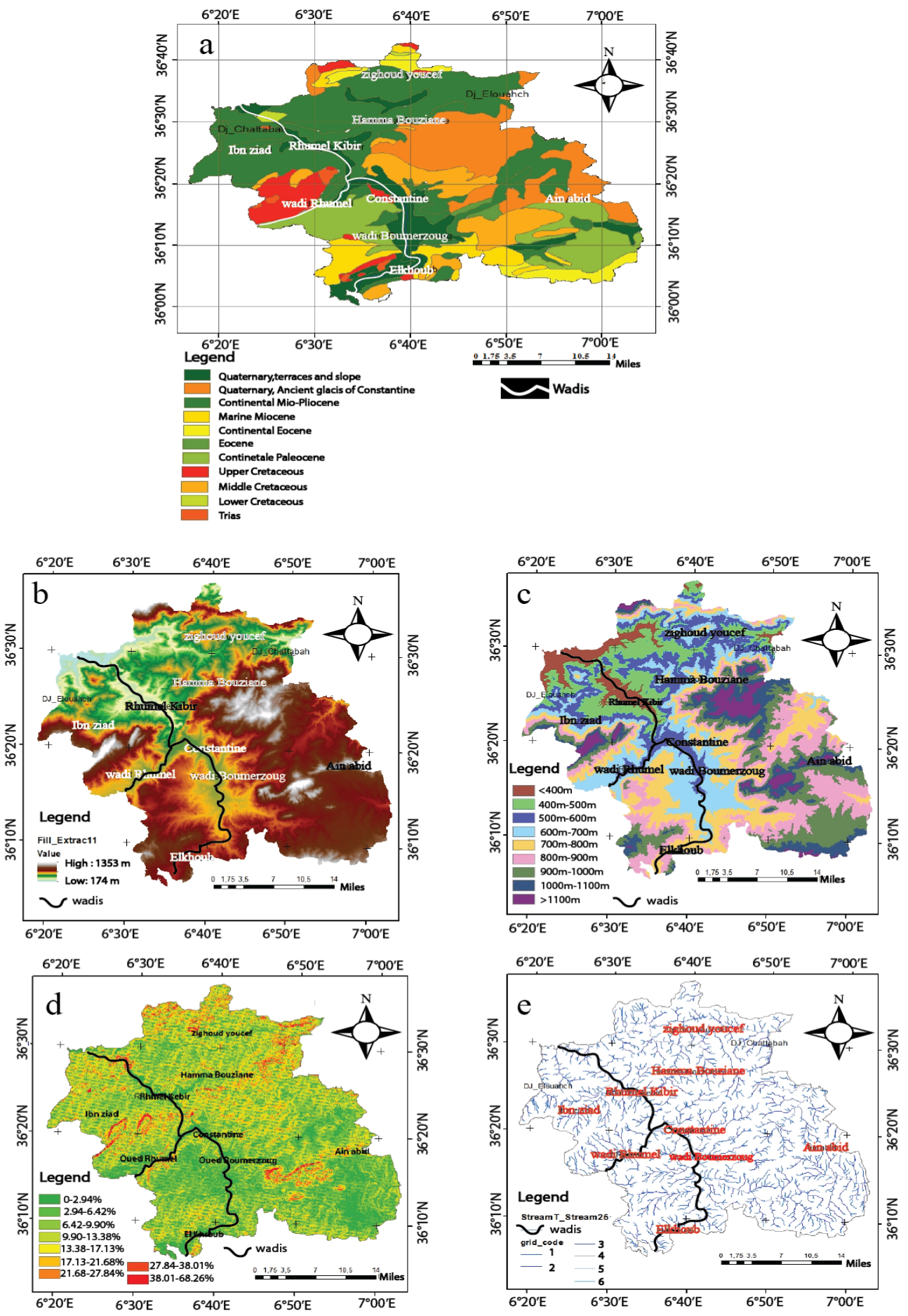

Figure 2. a) Geological map of the Constantine region1/200000, b) Digital terrain model, c) Hierarchy of the hydrographic network, d) Slope map, e) Hypsometric map (Source: figure 2a; Villa, 1978; figure 2b, 2c, 2d, 2e; Noureddine Rabahi) 

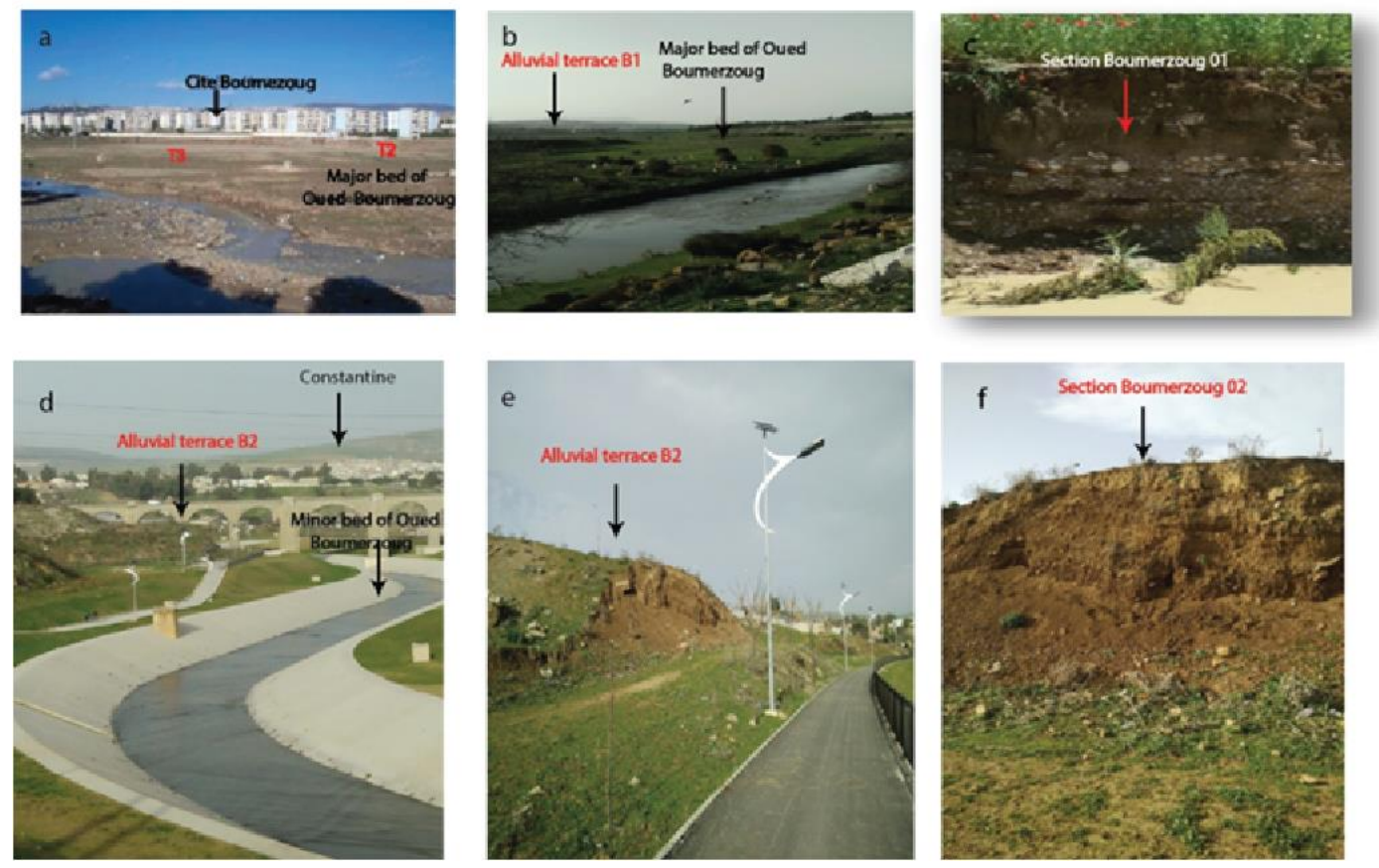

Figure 3. Morphology of the alluvial plain of Boumerzoug wadi with the different beds (a, b, c: undeveloped section of Boumerzoug wadi; $d, e$, f: developed section of Boumerzoug wadi)

(Source: Noureddine RABAHI)

\section{GEOLOGICAL SETTING}

To give a litho-stratigraphic overview of the different formations, and to specify their spatial distribution, the studied sections and their surrounding areas are made up of soil ranging from the Cretaceous to the Quaternary (figure 2a). The stratigraphic description concerns only the outcropping formations in the Constantine Basin (Rabahi, 2008; Farah, 1991).

According to the geological map of Constantine at 1/20000 (figure 2a), the studied section could be schematically subdivided into the following six domains.

1) The Neritic Constantine formation (Lower to Middle Cretaceous) corresponds to a succession of karstic limestone banks, found in the north-central sector of the study area.

2) The Tellian formations composed by grey, greenish marls, which may present inclusions ("young balls") related to the end of the Cretaceous period. They are well developed on the right bank of the Wadi Rhumel; their contact with the underlying formations corresponds to an erosion surface, preceding the continental deposits.

3) The Massylian flysch (Aptian-Albian age) recognized south-east of Constantine and on the left bank of the Boumerzoug wadi, are made up of alternating micro-breccia limestones and marly pelites.

4) The Miocene formations consist of clays, conglomerates, breccia, gypsum marls, pebble marls, and lacustrine limestones also, which correspond to continental deposits deposited in a subsident basin. Given their deposition method, it is hard to establish a stratigraphy, which changes from one place to another, as well as the lateral continuity of the levels, and their geographical extension does not exceed a few hundred meters.

5) The Pliocene formations correspond to the lacustrine limestones that form the wooded hills of the Djebel Hdj Baba south-west of Constantine by their sandy-conglomerate base and their reduced thickness. 
6) Quaternary formations are represented by coarse conglomerates and lacustrine limestones and alluvial deposits. In particular, Ancient Quaternary is mainly represented by the lacustrine limestone and the alluvial terraces of the Rhummel and Boumerzoug wadis. The other formations correspond to heterogeneous, thin, predominantly clayey slope deposits. Finally, the recent Quaternary is represented by three stepped alluvial terraces, recognized on both banks of the Rhummel and Boumerzoug wadis. It is silty, finely sandy and sandy with heterogeneous, rolled pebbles.

\section{MATERIALS AND METHODS}

After a field prospecting along Boumerzoug wadi, between the locality of Ouled Rahmoune and the confluence of Boumerzoug wadi with Rhumel wadi, two sections B1 and B2 were chosen (figure 1). For each level, the description of each layer, its thickness, limits of deposition, color variations, petrographic nature, texture, granulometry, gradation, and sedimentary features are essential before each sampling. The studied samples were collected and placed in plastic bags, then transported to the laboratory. After removal of the coarse fraction, granulometry study focuses on washing the sediment with the $2 \mathrm{~mm}$ sieve to separate the sandy fractions $(2 \mathrm{~mm}>$ $0.063 \mathrm{~mm})$ and the $0.063 \mathrm{~mm}$ sieve to separate the silt-clay fractions $(0.002 \mathrm{~mm}<0.063 \mathrm{~mm})$ (Miskovsky, 2002). Fine granulometry was performed by sedimentation analysis using Anderson's pipette to highlight the different silty fractions $(0.004 \mathrm{~mm}>\varnothing>0.063 \mathrm{~mm})$ and clay fraction $(<$ $0.002 \mathrm{~mm}$ ). Geochemical analyses of the following soil parameters, $\mathrm{pH}$ (according to AFNOR NF T90-008), Electrical Conductivity (EC) (Rodier et al., 2009), organic matter (OM) (AFNOR XP P 94- 047), carbonates $\left(\mathrm{CaCO}_{3}\right)$ (AFNOR NF ISO 10693), were performed at the Agronomic Sciences Laboratory (University of Batna 1, Algeria) and Civil Engineering Laboratory (University of Batna 2, Algeria) on homogenized and sifted sediment samples on $2 \mathrm{~mm}$ mesh stainless steel sieve.

\section{RESULTS}

\section{SEDIMENTOLOGY AND GEOCHEMISTRY OF SECTION B1}

Section B1 was lifted in a terrace located on the left bank of the Boumerzoug wadi, with geographic coordinates $06^{\circ} 39.779^{\prime} \mathrm{E}, 36^{\circ} 19.265^{\prime} \mathrm{N}$, and $564 \mathrm{~m}$ asl (figure 1). Over $1.90 \mathrm{~m}$, it superimposes three sequences of deposits, from bottom to top (figure 4)

Deposit sequence 1, with increasing gradient and thickness of $0.50 \mathrm{~m}$, begins with coarse sandy (B1-9) discordant on the Tellian formations (greyish marl intercalated with nodule limestone). The material becomes increasingly coarse, forming block pebbles (B1-8), with sandy to sand-clay matrix (B1-7) and centimetric stratification. The granulometry analysis shows a magnification from the base to the top, expressed by a sharp increase in sand contents from $50.33 \%$ to $70.76 \%$ and by a decrease in silt and clay contents from $29.07 \%, 10.60 \%$ to $26.70 \%$ and $3.14 \%$ respectively (figure 5). The carbonate contents are significant, ranging from $33.14 \%$ at the base of the sequence to $35.12 \%$ at the top. Organic matter contents are relatively high. They evolve inversely to those of $\mathrm{CaCO}_{3}$ with $5.55 \%$, from the base, up to $4.84 \%$ in the coarser levels towards the top of the sequence. The $\mathrm{pH}$ becomes more alkaline at the top of the sequence and varies very little, fluctuating around 7.0 to 8 . EC, which is high at the base of the sequence, $(903 \mu \mathrm{S} / \mathrm{cm})$ shows a slight decrease in the coarser levels towards the top $(855 \mu \mathrm{S} / \mathrm{cm})$ (Table 1).

Deposit sequence 2, with an increasing gradation and thickness of $0.50 \mathrm{~m}$, results very homogeneous; it rests on sequence 1 by a narrow and continuous surface. It starts with more or less fine sand (B1-6), which quickly becomes gravel and pebbles (B1-5) packed in a clayey to sandy-clay matrix (B1-4). The granulometry analysis shows a slow growth from the base upwards, which is expressed by a slight increase in the sand contents from $63.15 \%$ to $68.89 \%$, as well as the silt contents increase from $20.65 \%$ to $27.02 \%$, while the clay contents decrease from $16.20 \%$ to $4.09 \%$ (figure 5). $\mathrm{CaCO}_{3}$ contents are decreasing but remain still important, ranging from $19.89 \%$ at the base of the sequence to $18.50 \%$ at the top. The organic matter content remains relatively high, $8.08 \%$ 
from the base to $7.23 \%$ in the coarser levels towards the top. The $\mathrm{pH}$ shows stability throughout the sequence of 7.22 to 7.80 . EC is relatively high $(704 \mu \mathrm{S} / \mathrm{cm})$ at the base of the sequence and in the coarser levels $(799 \mu \mathrm{S} / \mathrm{cm})$, rising towards the top with a peak of $1070 \mu \mathrm{S} / \mathrm{cm}$ (Table 1).
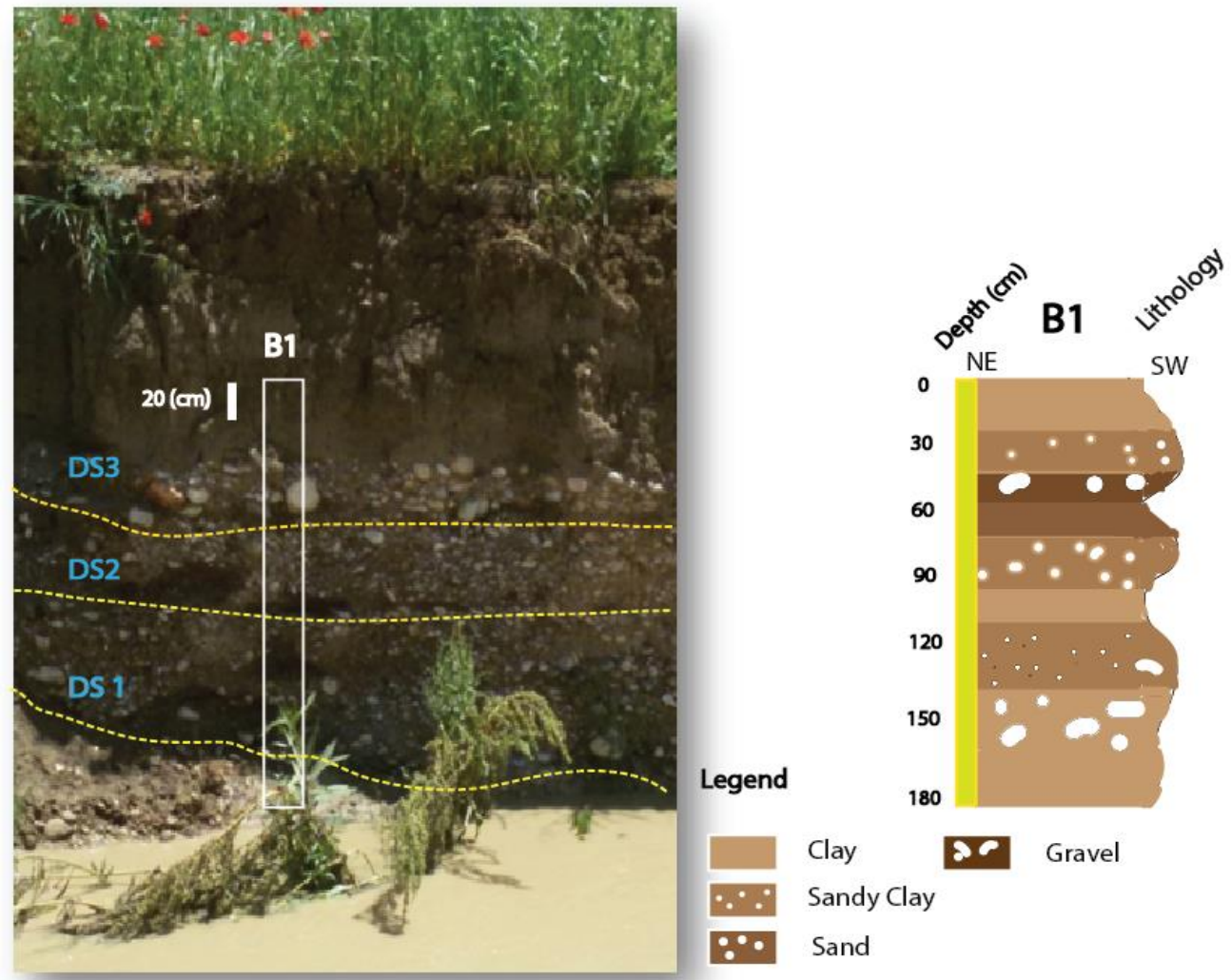

Clay

D. Gravel

Sandy Clay

Sand
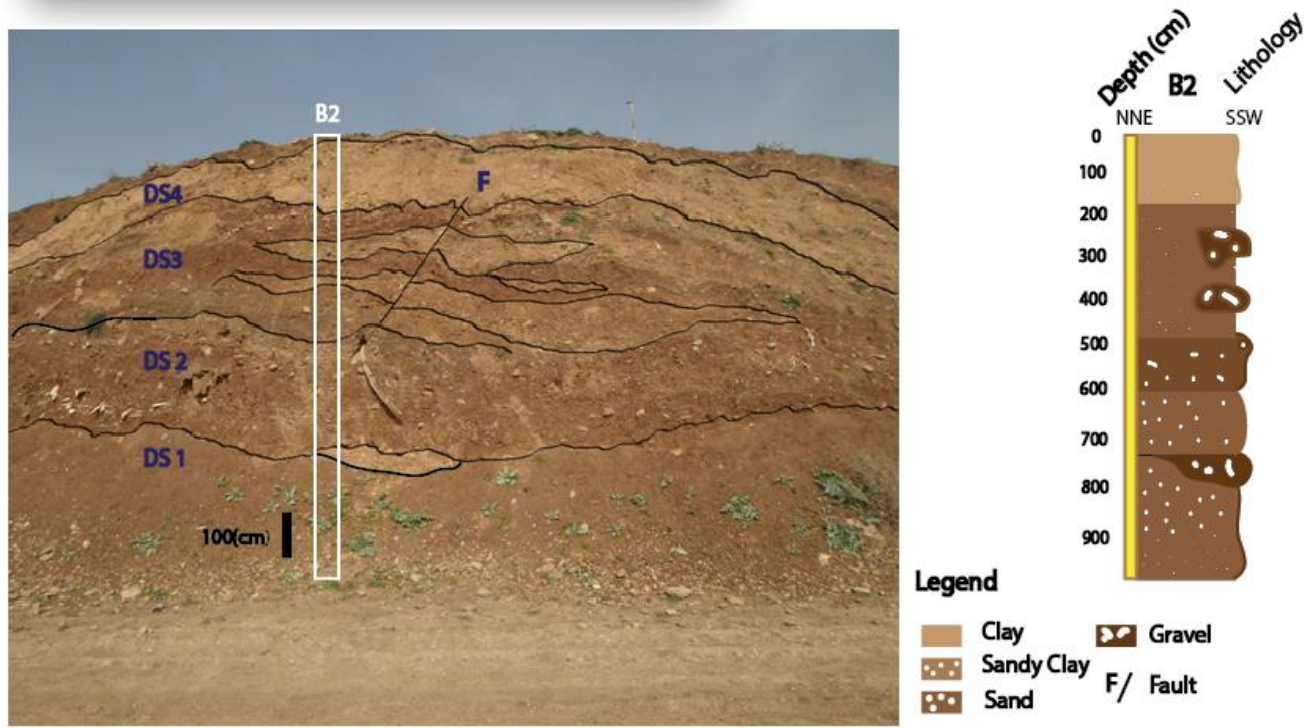

Figure 4. Sedimentary profiles and photographs of Boumerzoug wadi sections B1 and B2. Deposit sequence (DS); 
(Source: Noureddine RABAHI)

Table 1. Physic-geochemical analysis of the Boumerzoug wadi sediments

(Data source: Noureddine RABAHI)

\begin{tabular}{|c|c|c|c|c|c|c|c|c|c|}
\hline \multicolumn{5}{|c|}{ Granulometry } & \multicolumn{5}{|c|}{ Geochemistry } \\
\hline Sample & $\begin{array}{c}\text { Clay } \\
(\%)\end{array}$ & $\begin{array}{l}\text { Fine } \\
\text { Silt } \\
(\%)\end{array}$ & $\begin{array}{l}\text { Rude } \\
\text { Silt } \\
(\%) \\
\end{array}$ & $\begin{array}{c}\text { Sand } \\
(\%)\end{array}$ & $\mathrm{pH}$ & $\mathrm{pH}(\mathrm{KCl})$ & $\begin{array}{l}\text { EC } \\
(\mu \mathrm{S} / \mathrm{cm})\end{array}$ & $\begin{array}{l}\mathrm{OM} \\
(\%)\end{array}$ & $\begin{array}{l}\mathrm{CaCO}_{3} \\
(\%)\end{array}$ \\
\hline \multicolumn{10}{|c|}{ Section B1 } \\
\hline B1-1 & 14.28 & 28.13 & 25.18 & 32.41 & 7.92 & 8.44 & 821 & 8.70 & 12.36 \\
\hline B1-2 & 12.66 & 21.15 & 20.13 & 46.06 & 7.85 & 8.13 & 852 & 8.07 & 20.33 \\
\hline B1-3 & 3.15 & 28.13 & 18.91 & 49.81 & 7.06 & 7.58 & 900 & 6.84 & 23.15 \\
\hline B1-4 & 4.09 & 10.88 & 16.14 & 68.89 & 7.22 & 7.76 & 799 & 7.23 & 18.5 \\
\hline B1-5 & 11.32 & 9.92 & 12.15 & 66.61 & 7.55 & 8.00 & 1070 & 7.28 & 19.30 \\
\hline B1-6 & 16.20 & 14.14 & 06.51 & 63.15 & 7.80 & 8.20 & 704 & 8.08 & 19.89 \\
\hline B1-7 & 3.14 & 9.80 & 16.30 & 70.76 & 7.90 & 8.30 & 855 & 4.84 & 35.12 \\
\hline B1-8 & 3.77 & 4.05 & 22.48 & 69.70 & 7.23 & 7.71 & 853 & 5.11 & 32.15 \\
\hline B1-9 & 10.60 & 13.94 & 25.13 & 50.33 & 7.21 & 7.72 & 903 & 5.55 & 33.14 \\
\hline \multicolumn{10}{|c|}{ Section B2 } \\
\hline B2-1 & 28.98 & 18.12 & 16.71 & 36.19 & 7.0 & 7.50 & 270 & 9.70 & 10.33 \\
\hline B2-2 & 26.48 & 16.50 & 16.97 & 40.05 & 7.13 & 7.71 & 317 & 9.11 & 12.15 \\
\hline B2-3 & 15.12 & 11.54 & 15.22 & 58.12 & 7.46 & 7.90 & 403 & 4.80 & 34.04 \\
\hline B2-4 & 13.10 & 7.59 & 28.13 & 51.18 & 7.44 & 7.87 & 472 & 5.01 & 30.05 \\
\hline B2-5 & 9.87 & 15.26 & 30.15 & 44.72 & 7.53 & 7.92 & 510 & 5.44 & 26.12 \\
\hline B2-6 & 13.5 & 10.02 & 4.47 & 73.01 & 7.30 & 7.70 & 473 & 8.33 & 10.90 \\
\hline B2-7 & 6.77 & 16.09 & 7.18 & 69.96 & 7.48 & 7.90 & 500 & 6.01 & 20.13 \\
\hline B2-8 & 6.15 & 25.28 & 7.68 & 60.88 & 7.60 & 7.98 & 580 & 5.58 & 25.81 \\
\hline B2-9 & 1.22 & 4.22 & 24.43 & 70.13 & 8.00 & 8.03 & 860 & 6.13 & 26.81 \\
\hline B2-10 & 1.50 & 8.83 & 27.64 & 62.03 & 8.07 & 8.44 & 980 & 4.00 & 32.88 \\
\hline B2-11 & 2.86 & 7.48 & 28.96 & 59.70 & 8.29 & 8.50 & 1083 & 4.83 & 37.90 \\
\hline
\end{tabular}

Deposit sequence 3, with decreasing gradation and a thickness of $0.90 \mathrm{~m}$, is incomplete (figure 4). It is based on the previous sequence through a regular and continuous surface. It begins with a heterometric block pebbles (B1-3) composed of pebbles and gravel mainly carbonated and packaged in a black grey clay matrix. The sediment quickly becomes fine sandy (B1-2). It ends with a very homogeneous level of light sandy clay (B1-1), becoming very dark. The granulometry analysis shows a negative gradation from the bottom to the top, with a decrease in sand contents from $49.81 \%$ to $32.41 \%$ in favor of an increase in silt contents from $47.04 \%$ to $53.31 \%$ and clay contents from $3.15 \%$ to $14.28 \%$ (figure 5 ). $\mathrm{CaCO}_{3}$ contents remain more or less high, with a significant decrease from the base to the top of the sequence, ranging from $23.15 \%$ in the sands to $12.36 \%$ in the sandy clay levels. The organic matter content increases in the same direction from $7.58 \%$ to $8.44 \%$. The $\mathrm{pH}$ remains alkaline with values between 7.06 at the base of the sequence and 7.92 at the top. EC values still stand high, decreasing from 900 to $821 \mu \mathrm{S} / \mathrm{cm}$ (figure 5). 


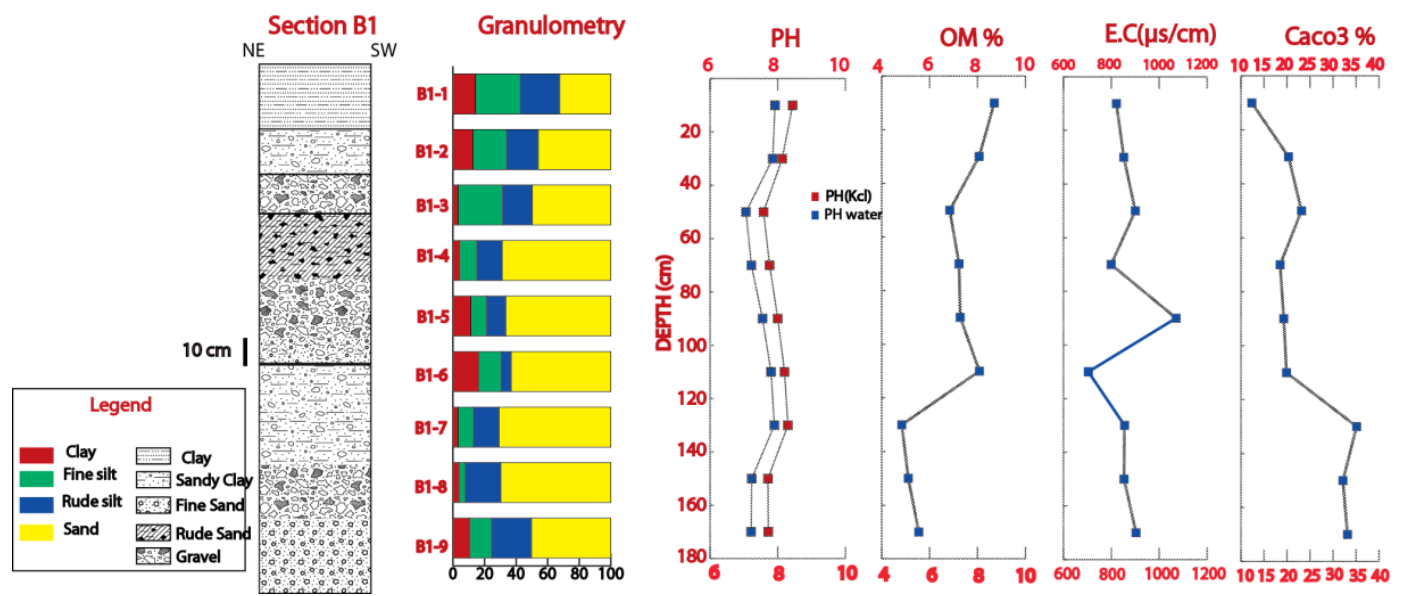

Figure 5. vertical profiles of the lithological, sedimentological and geochemical parameters of section B1 (Source: Noureddine RABAHI)

\section{SEDIMENTOLOGY AND GEOCHEMISTRY OF SECTION B2}

The B2 section was lifted in a terrace of more than $9.00 \mathrm{~m}$. It is located on the left bank of Boumerzoug wadi near Chaabet El Russes locality (geographic coordinates $6^{\circ} 37.970$ 'E, $36^{\circ} 20.486$ 'N, $539 \mathrm{~m}$ asl (figure 1). It shows four sequences, three of which with increasing gradation and the fourth upper sequence with negative gradation, as described below from the bottom to top (figure 4).
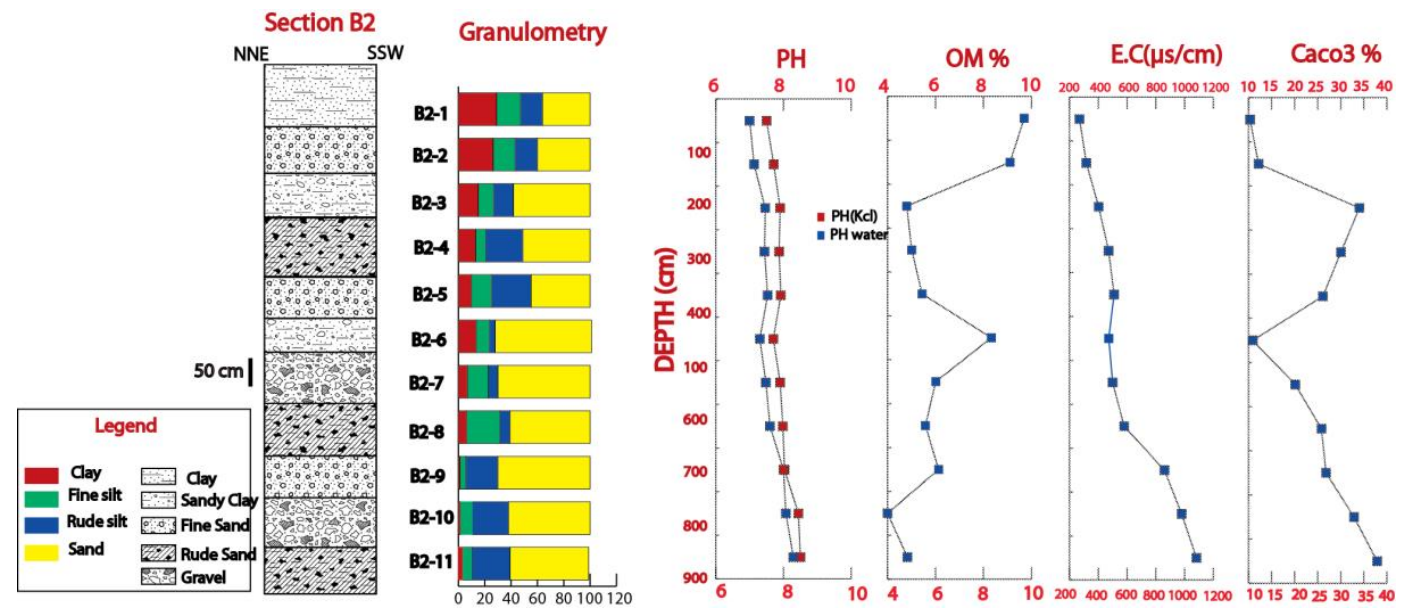

Figure 6. vertical profiles of the lithological, sedimentological and geochemical parameters of section B2 (Source: Noureddine RABAHI)

Deposit sequence 1, 2.00 m thick, begins with coarse sand (B2-11) packed in a sand, sandcarbonate matrix. The coarse material becomes increasingly heterometric (B2-10), whitish colored pebbles and gravel with carbonate cementing (B2-9) (figure 6). The granulometry analysis shows a rapid growth from the base to the top, expressed by a marked increase in sand contents. The contents pass from $59.70 \%$ at the base to $70.13 \%$ at the top of the sequence. Silt and clay contents decreased from $36.44 \%, 2.86 \%$ to $28.51 \%$ and $1.22 \%$ respectively (figure 6). $\mathrm{CaCO}_{3}$ content is huge, going from $37.90 \%$ at the base to $26.81 \%$ at the top of the sequence. OM contents show average values of $4.83 \%$ at the base, increasing up to $6.13 \%$ in the coarser levels towards the top 
of the sequence. The $\mathrm{pH}$ is alkaline, with negligible variations between 8.29 and 8 . EC, which is high at the base of the sequence $(1083 \mu \mathrm{S} / \mathrm{cm})$, shows a slight decrease in the coarser levels towards the top $(860 \mu \mathrm{S} / \mathrm{cm})$ (Table 1$)$.

Deposit sequence 2, $2.30 \mathrm{~m}$ thick, is in the form of beds (B2-8) with a more or less coarse material, very homogeneous and of varied color. It lies on the lower sequence with an irregular surface (figure 6). This sequence, starting with more or less coarse sand (B2-7), quickly becomes gravel and pebbles packed in a clay-sand matrix (B2-6). The granulometry analysis shows a rapid growth from the base to the top which is expressed by a marked increase in sand contents from $60.88 \%$ to $73.01 \%$. This analysis also shows a decrease in silt contents from $32.96 \%$ to $14.49 \%$ and an increase in clay contents from $6.15 \%$ to $13.5 \%$ (figure 6). $\mathrm{CaCO}_{3}$ content is still important, ranging from $25.80 \%$ at the base and decrease rapidly to $10.90 \%$ at the top. OM contents are relatively high, from $5.58 \%$ at the base to $8.33 \%$ towards the top of the sequence. The $\mathrm{pH}$ shows stability throughout the entire sequence, from 7.60 to 7.30 . EC remains relatively high (580 $\mu \mathrm{S} / \mathrm{cm})$ at the base of the sequence, rapidly decreasing $(473 \mu \mathrm{S} / \mathrm{cm})$ in the coarser levels towards the top (figure 6).

Deposit sequence 3, 3 m thick, begins with more or less fine sand (B2-5) that quickly becomes coarse sands (B2-4) packed in a grey clayey-sandy matrix (B2-3) (figure 6). The granulometry analysis shows a positive gradation from the base to the top with an increase in sand content from $44.72 \%$ to $58.12 \%$ in favor of a decrease in silt content $45.41 \%$ at the base of the sequence, $26.76 \%$ at the top and an increase in clays from $9.87 \%$ to $15.12 \%$ (figure 6 ). The carbonate content is around $26.13 \%$ in the fine sands at the base of the sequence and increases to $34.04 \%$ in the clay-sand level at the top. Organic matter contents decrease slightly from $5.44 \%$ to $4.80 \%$. The $\mathrm{pH}$ remains alkaline with values between 7.53 at the base of the sequence and 7.44 at the top. The electrical conductivity shows a stability of around $510 \mu \mathrm{S} / \mathrm{cm}$ and $403 \mu \mathrm{S} / \mathrm{cm}$.

Deposit Sequence 4, $2.00 \mathrm{~m}$ thick, is generally represented by laminated fine sands (B2), which pass to light yellow clays (B2-1) (figure 4). The granulometry analysis shows a negative gradation from the base to the top with a decrease in sand contents from $40.05 \%$ to $36.19 \%$ in favor of a slight increase in silt contents from $33.47 \%$ to $34.92 \%$ and clay contents from $26.48 \%$ to $28.98 \%$, which remains quite significant in this sequence (figure 6). $\mathrm{CaCO}_{3}$ content is equal to $12.15 \%$ in the sands at the base of the sequence, showing a decrease to $10.33 \%$ in the clayey level at the top. OM content remains very high at $9.11 \%$ to $9.70 \%$. The $\mathrm{pH}$ keeps alkaline values ranging between 7.13 at the base of the sequence and 7.00 at the top. EC decreases and gives values between $317 \mu \mathrm{S} / \mathrm{cm}$ and $270 \mu \mathrm{S} / \mathrm{cm}$ (figure 6).

\section{DISCUSSION AND CONCLUSION}

Lithological and sedimentological studies of sections B1 and B2 highlighted that the lower deposit sequences show increasing gradation. They generally begin with clays, sandy clays, and fine sands on which the deposits progressively become coarse, and pass to gravel and pebbles. Variations in sediment texture can be interpreted in terms of current energy (Djerrab et al., 2012). Thus, the presence of high proportions of gravel and pebbles at the top of the sequences would be associated with setting up under stronger dynamic conditions (Djerrab et al., 2012). Conversely, the robust presence of silty sands and clays at the base of the sequences (figures 5,6) indicates flows with lower competence and a more regular regime (Ballais and Benazzouz, 1994). The upper deposit sequences in both sections B1 and B2 show a decreasing gradation starting with heterometric pebbles which gradually becomes fine sands (B1), passing to clays (B2). The tops of the upper sequences are predominated by silty-sandy sediments, indicating sedimentation by rolling or saltation under the effect of a low to moderate current, with a slowing of sedimentation in coarse elements at the sequence bases. The levels of gravel and coarse sand were probably deposited during flood periods.

The $\mathrm{pH}$ values recorded in the alluvial deposits of Boumerzoug wadi underline their alkaline characters, sometimes tending towards neutrality. Alkalinity reflects the nature of the sediments, 
Noureddine RABAHI, Foued DJAIZ, Nabil DEFAFLIA, et al.,

dominated by a limestone source rock and silty-clay soils (Nassali et al., 2002; Keddari et al., 2019). The EC high values of the alluvium in the Boumerzoug wadi are due to the enrichment with monovalent and bivalent ions (Nassali et al., 2002). EC is fairly consistent with the conductivity of freshwater sediments despite a few peaks exceeding $1070 \mu \mathrm{S} / \mathrm{cm}$ and $1083 \mu \mathrm{S} / \mathrm{cm}$ (Keddari et al., 2019). These values reflect a sometimes-high mineralization that can be attributed to the presence of sebkhas upstream of the sub-basin in the Ain M'lila region. The OM high levels, ranging from $4.84 \%$ to $8.70 \%$ in section $\mathrm{B} 1$ and from $4 \%$ to $9.70 \%$ in section $\mathrm{B} 2$, are probably due to the degradation of dead cells of the river's fauna and flora as well as to the leaching of the surrounding soils (Abdallaoui, 1998). From a climatic point of view, this probably denotes a climate change, with a shift from a humid to a semi-arid climate (Djerrab et al., 2012).

The vertical increase in carbonate contents and the decrease in organic matter contents would be controlled by the conditions of sediment placement by hydrodynamics of the water, besides their lithological origins. Indeed, the fine sedimentation comes essentially from the erosion of the Tellian marls of the Upper Cretaceous and the clayey-marly-gypsum formations of the Miocene. These fine particles charged with mineral and organic particles are associated to flooding periods of Boumerzoug wadi and runoff from mountain slopes. In effect, the study of the different geochemical parameters converges to the same direction as those of the sedimentological ones, generally showing a negative evolution towards the higher sequences, thus confirming the hydrological and climatic changes.

In general, alluvial formations can be divided into two deposition phases, translated in two climatic cycles. The first one, which affects the lower part of the alluvial formations, characterizes a subhumid to humid climate with more or less important rainfall, with intercalations of dry periods. The second cycle, with dryer climatic conditions and medium to low rainfall, is probably similar to a semi-arid climate.

Finally, the temporal fluctuations of the geochemical parameters would result from the hydrodynamics of the water, as well as their higher concentration in the dry season and its dilution in the wet season.

\section{REFERENCES}

Abdallaoui, A. (1998). Contribution à l'étude du phosphore et des métaux lourds contenus dans les sédiments et de leur influence sur les phénomènes d'eutrophisation et de la pollution: Cas du bassin versant de l'Oued Beht et de la retenue de barrage El Kansera.

Ballais, J. L., \& Benazzouz, M. (1994). Données nouvelles sur la morphogenèse et les paléo-environnements tardiglaciaires et holocènes dans la vallée de l'oued Chéria-Mezeraa (Nemencha, Algérie orientale). Méditerranée, 80(3), 59-71.

Bougdal, R. (2007). Urbanisation et mouvements de versants dans le contexte géologique et géotechnique des bassins néogénes d'Algérie du Nord (Doctoral dissertation, Alger).

Bourenane, H., \& Bouhadad, Y. (2021). Spatial analysis, assessment and mapping of flood hazard in the alluvial plains of Boumerzoug and Rhumel (city of Constantine, north-eastern Algeria): application to development and urban planning projects. Bulletin of Engineering Geology and the Environment, 80(2), 1137-1155.

Côte, M. (1974). Les régions bioclimatiques de l'Est algérien. Univ. Constantine, C.U.R.E.R., Ronéot, Algérie pp 6,

Djerrab, A., Zedam, R., Camps, P., Defaflia, N., Abdessadok, S., Triki, D., ... \& Bahra, N. (2012). Étude sédimentologique et magnétique d'une séquence alluviale du Pléistocène supérieur-Holocène de l'oued Adaila (El Ma Labiod, Tébessa, Algérie) et indications paléoenvironnementales. Quaternaire. Revue de l'Association française pour l'étude du Quaternaire, 23(3), 227-240.

Farah, A. S. (1991). Etude du comportement hydrochimique d'un oued en zone méditerranéenne semi-aride d'Afrique du Nord et de ses causes naturelles et anthropiques: l'oued Rhumel, Constantinois, Algérie (Doctoral dissertation, Orléans). 
Keddari, D., Afri-Mehennaoui, F. Z., Smatti-Hamza, I., Djeddi, H., Sahli, L., \& Mehennaoui, S. (2019). Évaluation du niveau de contamination par les éléments traces métalliques (cadmium, cuivre, nickel et zinc) des sédiments de l'oued Boumerzoug et ses affluents, et leur transfert vers la chénopodiacée spinacia oleracea (L.). Revue des Sciences de l'Eau/Journal of Water Science, 32(3), 255-273.

Mébarki, A. (1984). Ressources en eau et aménagement en Algérie. Le bassin du Kébir-Rhumel. Alger, Office des Publications Universitaires Algérie pp 302.

Miskovsky, J.C. (2002). Géologie de la Préhistoire, méthodes, techniques; Applications, ed Association pour l'étude de l'environnement géologique de la Préhistoire, Paris, Géopré, Presses universitaires de Perpignan, $1519 p$.

Nassali, H., Bouih, H. B., \& Srhiri, A. Influence des eaux usées sur la dégradation de la qualité des eaux du lac Fouarate au maroc Proceedings of International Symposium on Environmental Pollution Control and Waste Management 7-10 January 2002. Tunis (EPCOWM'2002), 3-14.

Rabahi, N. (2008). La Série Néritique du Constantinois Central «Massif du Chattabah, Djebel Felten» Lithostratigraphie, Sédimentologie et Caractérisation Hydrogéologique «Région de Constantine» (Doctoral dissertation, Université de Batna 2).

Rodier J., Legube B., Merlet N., Brunet R; (2009). L'analyse de l'eau. Eaux naturelles, eaux résiduaires, eaux de mer. 9e édition, Dunod, Paris, France, 1529 p.

Salvia-Castellvi, M., Scholer, C., \& Hoffmann, L. (2002). Comparaison de différents protocoles de spéciation séquentielle du phosphore dans des sédiments de rivière. Revue des sciences de l'eau/Journal of Water Science, 15(1), 223-233.

Villa J M. (1977). Carte de l'Algérie aul/200 000, feuille de Constantine (P-Q; 3-4). Publ. comm. Serv. Carte Geol, Algérie/SONATRACH, not. Expl. Détaillée, 45p.

Wengler, L., Vernet, J. L., Ballouche, A., Damblon, F., \& Michel, P. (1992). Signification dee paléomilieux et évolution du climat au Maghreb. Le Maroc oriental au Pléistocène récent. Bulletin de la Société Botanique de France. Actualités Botaniques, 139(2-4), 507-529.

Submitted:

March 08, 2021
Revised:

May 07, 2021
Accepted and published online June 02, 2021 